\title{
Relationships between physical and chemical characteristics and calculated metabolizable energy values in barley and oats with highly variable volume weights
}

\author{
Maija-LiIsa Salo \\ Department of Animal Husbandry, University of \\ Helsinki, 00710 Helsinki 71, Finland
}

\begin{abstract}
. 61 samples of barley with a volume weight of $38-75 \mathrm{~kg} / \mathrm{hl}$, and 49 oat samples with a volume weight of $40-65 \mathrm{~kg} / \mathrm{hl}$ were analyzed for physical and chemical characteristics. The approximate metabolizable energy (ME) value was calculated from the composition.

The physical characteristics varied more, but the starch content less, in barley than in oats. There was also a negative correlation between starch and crude protein, and ether extract level in barley, but not in oats. Therefore the difference between the ME values of the best and the poorest samples was only $12 \%$ for barley, but $27 \%$ for oats.

Both the starch and the crude protein content predicted the ME value well: $\mathrm{R}^{2}$ of starch was $78-94 \%$, and that of crude fibre $55-84 \%$. The volume weight still gave a good indication for barley, but not at all for oats.
\end{abstract}

\section{Introduction}

Barley is known to have a very constant feeding value: its net energy content is only slightly or not at all affected by the stage of ripeness, the location or the year (MADSEN et al. 1972, Thомке 1972), nor even by its variety (Schulz and Oslage 1969, Peers and Taylor 1977). However, if the volume weight is very low, the F.U. value for pigs (SUNDSTøL 1970) and the Mcal.value for chickens (SIBBALD and PrICE 1976) is slightly reduced. The crude protein content varies more than the energy value, being influenced by the variety, climatic conditions and nitrogen fertilization (REKUNEN 1969, SchULZ and Oslage 1969, Gaarbo Thomsen 1977, Peers and Taylor 1977).

Oats, instead, are more inconsistant. Their high and variable hull content reflects in the feeding value causing variation (Thомке 1961, Sibbald and PRICE 1977). This fact has been taken into account in the Feed Tables.

Barley and oats are the main cereals cultivated in Finland. If the summer is cold, the crops do not get to the full-ripeness stage. They can still be damaged by frost or even a fall of snow. Such grains are not of full value.

The motive for this study was the low weight of cereals after the cold and rainy summer of 1977. The purpose was to evaluate the variation scale of the 
physical and chemical characteristics of barley and oats, the relationships between them, and to establish the parameters, which would most suitably characterize the nutritive value of these crops.

\section{Materials and methods}

61 samples of barley from 14 different varieties, and 49 samples of oats, from 10 varieties were collected from various parts of Finland. The area ranged from a latitude $60^{\circ}$ to $64^{\circ}$. The majority of the samples were from the summer of 1977, but a small proportion were from earlier, climatically normal years.

\section{Analytical methods}

The volume weight and the 1000 -kernel weight were measured using apparatus and methods of the Research Laboratory of Finnish State Granary. A slight precleaning of the grain was included the method. The results were corrested to $85 \%$ grain DM content. The hull content of the oats was determined from five gram samples. The moisture of the grains was determined by drying for $48 \mathrm{~h}$ at $103^{\circ} \mathrm{C}$.

The chemical analyses were made on the same batch of grains as were used for the volume weight measurements. The grains were ground using a 0.5 $\mathrm{mm}$ sieve.

The common feed analyses were made according to standard methods. The starch was determined by the amyloglucosidase method but without ethanol extraction in order to include the sugars (SALO and SALmi 1968). The sugar content of these grains is only $1-2 \%$.

\section{Calculation of metabolizable energy value}

A metabolizable energy (ME) value, even an approximate one, was necessary for the comparison of various grain samples. The ME value for pigs was calculated on the basis of starch, ether extract and crude protein contents as follows: For the starch the gross energy value, $4.1 \mathrm{kcal} / \mathrm{g}$, was used, because the starch of cereals is totally digested by pigs (SALO 1965, 1971). The contents of ether extract and crude protein were multiplied with factors which were calculated according to average digestion coefficients from Feed Tables for pigs, and the Mcal values of digestible nutrients. The coefficients used for the ether extract were $\mathbf{5 . 0}$ for barley and $\mathbf{7 . 1}$ for oats and those for crude protein 3.7 and 3.3 , respectively.

The ME values thus obtained were too low, because the pig is cabable of digesting a great deal of the hemicellulose of the kernel; only the hulls are of no value. The digestibility of the hemicellulose of the wheat bran is nearly $50 \%$ (SALo 1965). To correct the figures to correspond to the normal ME level, they were multiplied by a factor, which was obtained by comparing them with the ME values from the Feed Tables for grains with a similar composition (ERIKsson et al. 1972). The corrected values, expressed as MJ, are presented in Tables 1 and 2. The corresponding F. U. values, corrected to $87 \% \mathrm{DM}$ 
content of grains are also presented (kg/F.U.). The ratio Mcal./F. U. was taken from NJF's Feed Tables (Anon. 1969).

Although the calculated ME values are not exact and the level for oats perhaps is a little too high, they agree with each other.

\section{Results and discussion}

\section{Composition and nutritive value}

As examples of the composition, Tables 1 and 2 present the physical and chemical characteristics and the calculated energy values of the most common varieties of both cereals, and further, the averages of the whole materials. Nine samples of barley belonged to two-rowed varieties and the rest to multirowed ones, but there were no clear differences in composition attributable to this property or, on the whole, between different varieties of barley and of oats.

The variation ranges over the whole materials, 61 barley samples and 49 oat samples, were as follows:

\begin{tabular}{|c|c|c|}
\hline Volume weight $(87 \%$ DM $), \mathrm{kg} / \mathrm{hl} \quad .$. & $38.4-75.3$, oats & $39.8-64.9$ \\
\hline 1000-kernel w. (87 \% DM), g & $22.2-50.7$ & $22.7-42.1$ \\
\hline Hulls, $\%$.............. & & $20.4-43.3$ \\
\hline Starch + sugars, $\%$ of DM .. & $51.5-61.7$ & $37.5-52.6$ \\
\hline Crude protein, $\%$ of DM & $9.9-15.5$ & $9.7-15.8$ \\
\hline$\%$ of DM ........................ & $1.7-2.8$ & $4.8-7.8$ \\
\hline \% of DM & $4.1-7.4$ & $7.2-15.0$ \\
\hline \% of DM & $2.4-3.4$ & $2.5-4.2$ \\
\hline MJ ME/kg DM & $12.61-14.22$ & $10.42-14.29$ \\
\hline (2) & $1.02-1.15$ & $1.03-1.41$ \\
\hline Pepsin solubility of $\mathrm{CP}$ & $73.2-84.4$ & $74.9-87.6$ \\
\hline
\end{tabular}

The physical characteristics varied more, but the starch content less, in barley than in oats. This is one reason for the fact that the difference between the highest and lowest ME values over 61 barley samples was only $12 \%$, whereas over 49 oat samples it was $27 \%$. The result is in agreement with the finding that barley reaches its full nutritive value many weeks before the full-ripeness stage (MAdsen et al. 1972, Тномке 1972). This does not appear to be true with the oats. One has of course, to bear in mind, that oats require a somewhat longer growth period than barley. However, the conclusion can be drawn that even in a bad year the nutritive value of barley is fairly normal, even when its volume weight is low. The oats however, though grown in the same conditions, may possess only three fourths of their normal feeding value.

The variation of crude protein content was the same for both cereals. A part of samples were also analyzed for pepsin soluble crude protein. On average, the high pepsin solubility appeared to be related to the high level of crude protein. The solubility of oat protein was a little higher than that of barley, irrespective of the fact, that about $6 \%$ of oat protein arises from the low-soluble protein of hulls. The hulls contain $3.0 \%$ crude protein of DM with a pepsin solubility of $39 \%$. 
Table 1. The physical and chemical characteristics of the barley variety Otra (16 samples), and the averages of all 61 barley samples.

\begin{tabular}{|c|c|c|c|c|c|c|c|c|c|}
\hline $\begin{array}{l}\text { Volume } \\
\text { weight } \\
\mathrm{kg} / \mathrm{hl}^{1} \text { ) }\end{array}$ & $\begin{array}{r}1000- \\
\text { kernel } \\
\text { w.g. }{ }^{1} \text { ) }\end{array}$ & $\begin{array}{c}\text { Starch and } \\
\text { sugars }\end{array}$ & $\begin{array}{r}\% \\
\text { Crude } \\
\text { protein }\end{array}$ & $\begin{array}{l}\text { of DM } \\
\text { Ether } \\
\text { extract }\end{array}$ & $\begin{array}{r}\text { Crude } \\
\text { fibre }\end{array}$ & $\overline{\text { Ash }}$ & $\begin{array}{c}\text { MJ } \mathrm{ME} \\
/ \mathrm{kg} \text { DM } \\
2)\end{array}$ & $\begin{array}{c}\text { PS- } \% \\
\text { of CP } \\
3 \text { ) }\end{array}$ & $\begin{array}{c}\text { kg/F.U. } \\
\left(\begin{array}{ccc}87 & \% & \text { DM }) \\
4) & \end{array}\right.\end{array}$ \\
\hline 72.2 & 50.7 & 59.2 & 13.7 & 2.2 & 4.1 & 2.7 & 14.12 & 82.5 & 1.03 \\
\hline 70.5 & 40.4 & 57.3 & 13.6 & 2.3 & 5.0 & 2.7 & 13.77 & & 1.05 \\
\hline 68.1 & 40.0 & 55.6 & 13.9 & 2.3 & 5.2 & 2.7 & 13.49 & 82.1 & 1.07 \\
\hline 66.6 & 34.5 & 61.4 & 10.0 & 2.1 & 5.5 & 2.5 & 13.88 & 77.0 & 1.04 \\
\hline 61.3 & 33.2 & 59.5 & 11.1 & 2.4 & 5.4 & 2.6 & 13.78 & 80.2 & 1.05 \\
\hline 61.2 & 30.7 & 55.7 & 13.7 & 2.2 & 5.9 & 2.7 & 13.45 & 80.1 & 1.08 \\
\hline 60.7 & 33.7 & 60.0 & 11.7 & 2.2 & 5.3 & 2.5 & 13.93 & & 1.04 \\
\hline 60.2 & 31.7 & 60.6 & 9.9 & 2.4 & 5.7 & 3.0 & 13.78 & 73.2 & 1.05 \\
\hline 58.7 & 34.0 & 57.2 & 13.0 & 2.2 & 5.8 & 2.7 & 13.62 & 78.5 & 1.06 \\
\hline 57.9 & 34.9 & 57.3 & 12.5 & 2.2 & 5.8 & 2.6 & 13.55 & & 1.07 \\
\hline 55.2 & 34.1 & 58.1 & 12.9 & 2.4 & 5.7 & 2.7 & 13.82 & 79.7 & 1.05 \\
\hline 54.5 & 35.4 & 58.3 & 11.9 & 2.4 & 5.5 & 2.8 & 13.69 & 77.0 & 1.06 \\
\hline 53.4 & 30.5 & 56.0 & 11.0 & 2.6 & 6.8 & 2.8 & 13.14 & 79.2 & 1.10 \\
\hline 53.3 & 30.7 & 56.4 & 12.3 & 2.2 & 6.1 & 2.8 & 13.48 & 76.4 & 1.08 \\
\hline 52.6 & 31.9 & 55.5 & 12.6 & 2.2 & 5.9 & 3.1 & 13.23 & & 1.10 \\
\hline 38.4 & 26.6 & 51.5 & 12.8 & 2.8 & 7.4 & 2.6 & 12.64 & 75.9 & 1.15 \\
\hline 59.1 & 34.6 & 57.5 & 12.3 & 2.3 & 5.7 & 2.7 & 13.58 & 78.5 & 1.07 \\
\hline \pm 8.3 & \pm 5.5 & \pm 2.4 & \pm 1.3 & \pm 0.2 & \pm 0.7 & \pm 0.2 & \pm 0.36 & & \\
\hline 60.2 & 33.2 & 57.4 & 12.7 & 2.2 & 5.6 & 2.8 & 13.60 & 79.6 & 1.07 \\
\hline \pm 7.5 & \pm 5.6 & \pm 2.5 & \pm 1.3 & \pm 0.2 & \pm 0.7 & \pm 0.2 & \pm 0.40 & & \\
\hline
\end{tabular}

1) Calculated to $87 \%$ DM, ${ }^{2}$ ) Calculated from the starch, crude protein and ether extract contents, see text; ${ }^{3}$ ) Pepsin solubility of CP; ${ }^{4}$ ) F. U. $=0.7 \times$ starch units.

\section{Relationships between characteristics}

Correlation coefficients between physical and chemical characteristics and calculated ME values are presented for all samples in Tables 3 and $\mathbf{5}$, and for the most common varieties in Tables 4 and 6 .

Some differences appeared between the whole material and one variety, but for most the correlation coefficients accorded. Highly significant positive correlations $(\mathrm{P}<0.001)$, uniformly in both matrixes, proved to be between starch and ME values in both cereals, and in barley also between volume weight and 1000-kernel weight, and ME value. Highly negative ones appeared between crude fibre and many characteristics in both cereals, in oats also between hulls and many characteristics. Most relationships found for barley are in agreement with those presented by SibBald and PRICE (1976). In oats the agreement is lower, perhaps because their material contained some naked varieties.

The correlation matrixes show that starch has very significant effect on the ME value, the finding of which is not surprising because starch is the main 
Table 2. The physical and chemical characteristics of the oat variety Ryhti (21 samples), and the averages of all 49 oat samples.

\begin{tabular}{|c|c|c|c|c|c|c|c|c|c|c|}
\hline \multirow{2}{*}{$\begin{array}{l}\text { Wolume } \\
\text { weight } \\
\mathrm{kg} / \mathrm{hl}^{1} \text { ) }\end{array}$} & \multirow{2}{*}{$\begin{array}{l}1000- \\
\text { kernel } \\
\left.\text { w.g. }{ }^{1}\right)\end{array}$} & \multirow[b]{2}{*}{$\begin{array}{c}\text { Hulls } \\
\%\end{array}$} & \multicolumn{4}{|c|}{$\%$ of DM } & \multirow[b]{2}{*}{ Ash } & \multirow{2}{*}{$\begin{array}{c}\mathrm{MJ} \text { ME } \\
/ \mathrm{kg} \text { DM } \\
\left.{ }^{2}\right)\end{array}$} & \multirow{2}{*}{$\begin{array}{c}\text { PS- } \% \\
\text { of CP } \\
\text { 3) }\end{array}$} & \multirow{2}{*}{$\begin{array}{c}\mathrm{kg} / \mathrm{F} . \mathrm{U} . \\
(87 \% \text { DM }) \\
4)\end{array}$} \\
\hline & & & $\begin{array}{c}\text { Starch and } \\
\text { sugar }\end{array}$ & $\begin{array}{l}\text { Crude } \\
\text { protein }\end{array}$ & $\begin{array}{l}\text { Ether } \\
\text { extract }\end{array}$ & $\begin{array}{r}\text { Crude } \\
\text { fibre }\end{array}$ & & & & \\
\hline 64.9 & 36.2 & 20.4 & 48.6 & 14.8 & 5.9 & 8.3 & 3.1 & 13.29 & 84.6 & 1.11 \\
\hline 60.0 & 38.0 & 22.8 & 43.6 & 14.2 & 5.5 & 11.6 & 2.9 & 12.11 & & 1.21 \\
\hline 57.2 & 34.4 & 20.6 & 44.1 & 13.9 & 5.3 & 11.6 & 4.2 & 12.11 & & 1.21 \\
\hline 56.1 & 36.3 & 25.4 & 42.4 & 11.8 & 5.5 & 13.7 & 3.4 & 11.54 & 84.3 & 1.27 \\
\hline 55.7 & 34.0 & 23.9 & 49.0 & 12.3 & 6.6 & 10.6 & 3.0 & 13.22 & 83.6 & 1.11 \\
\hline 54.0 & 38.4 & 23.4 & 41.9 & 10.9 & 6.0 & 13.7 & 3.3 & 11.48 & 80.9 & 1.28 \\
\hline 53.7 & 33.9 & 23.6 & 50.5 & 12.1 & 5.2 & 10.5 & 3.1 & 13.01 & 82.1 & 1.13 \\
\hline 53.5 & 37.1 & 24.4 & 43.0 & 10.6 & 5.9 & 13.9 & 3.2 & 11.61 & 80.2 & 1.27 \\
\hline 53.2 & 30.1 & 22.9 & 48.4 & 14.7 & 5.6 & 10.2 & 3.0 & 13.14 & 87.6 & 1.12 \\
\hline 51.9 & 37.0 & 23.9 & 47.4 & 10.7 & 6.0 & 11.8 & 3.6 & 12.48 & 81.7 & 1.18 \\
\hline 51.9 & 42.1 & 22.0 & 45.4 & 12.5 & 6.2 & 112 & 3.6 & 12.44 & & 1.18 \\
\hline 51.6 & 32.9 & 22.9 & 49.4 & 15.6 & 5.4 & 9.1 & 2.9 & 13.40 & & 1.10 \\
\hline 51.1 & 35.1 & 25.0 & 44.0 & 12.1 & 6.7 & 12.5 & 3.4 & 12.28 & 83.2 & 1.20 \\
\hline 51.0 & 35.3 & 25.4 & 42.5 & 11.4 & 5.9 & 13.8 & 3.8 & 11.64 & 80.8 & 1.26 \\
\hline 49.8 & 37.2 & 23.0 & 44.4 & 12.5 & 5.4 & 12.3 & 3.8 & 11.99 & & 1.23 \\
\hline 48.5 & 32.2 & 25.5 & 44.5 & 11.1 & 5.4 & 12.9 & 4.1 & 11.80 & 81.3 & 1.25 \\
\hline 48.1 & 33.6 & 26.9 & 47.3 & 12.2 & 6.8 & 11.7 & 3.1 & 12.95 & 80.0 & 1.14 \\
\hline 47.1 & 25.7 & 35.1 & $4 c .6$ & 10.8 & 4.8 & 14.0 & 3.8 & 10.83 & 78.6 & 1.36 \\
\hline 46.8 & 36.0 & 24.7 & 49.7 & 10.7 & 5.5 & 11.4 & 3.3 & 12.75 & & 1.15 \\
\hline 43.8 & 31.5 & 26.5 & 47.9 & 11.3 & 5.6 & 12.6 & 3.3 & 12.53 & 78.9 & 1.17 \\
\hline 40.2 & 29.8 & 33.5 & 39.9 & 11.4 & 5.9 & 14.9 & 4.2 & 11.15 & 81.9 & 1.32 \\
\hline 51.9 & 34.6 & 24.8 & 45.4 & 12.3 & 5.8 & 12.0 & 3.4 & 12.27 & 81.9 & 1.20 \\
\hline \pm 5.4 & \pm 3.5 & +3.6 & \pm 3.2 & \pm 1.5 & \pm 0.5 & \pm 1.7 & \pm 0.4 & \pm 0.74 & & \\
\hline 52.3 & 33.5 & 25.6 & 45.5 & 12.5 & 5.9 & 11.9 & 3.2 & 12.35 & 82.5 & 119 \\
\hline \pm 5.7 & +4.4 & \pm 4.3 & \pm 3.4 & +1.6 & \pm 0.5 & \pm 1.7 & +0.4 & \pm 6.79 & & \\
\hline
\end{tabular}

1-4) See footnotes, Table 1.

source of energy in grains. On the volume weight starch has a lesser effect, especially in the case of oats.

Crude protein is the other main nutrient, but it has a positive influence upon the magnitudes of ME value and volume weight only in oats because, in barley, there is a high negative correlation between the protein and starch contents. This finding confirms the results of SibBald and PRICE (1976).

The crude fat content of barley is low and negatively related to the starch and protein. Oats contain more fat, and it is slightly positively correlated with starch. Consequently, the fat level has a positive influence upon the ME value of oats, whereas the reverse is true in the case of barley.

The negative correlations between the three main nutrients, together with the fairly stable starch content, explain the constant energy value of barley: 
Table 3. Correlation coefficients between physical and chemical characteristics of barley, all samples $\mathrm{n}=61$.

\begin{tabular}{llccccccc}
\hline Characteristics & 1 & 2 & 3 & 4 & 5 & 6 & 7 & 8 \\
\hline 1. Volume w. & 1.00 & & & & & & & \\
2. 1000-kr. W. & $+.67^{3}$ & 1.00 & & & & & & \\
3. Starch + sugars & $+.48^{3}$ & $+.50^{3}$ & 1.00 & & & & & \\
4. Ether extract & $-.26^{1}$ & -.05 & -.10 & 1.00 & & & & \\
4. Crude protein & +.12 & +.16 & $-.49^{3}$ & -.10 & 1.00 & & & \\
6. Crude fibre & $-.58^{3}$ & $-.57^{3}$ & $-.65^{3}$ & -.01 & -.08 & 1.00 & & \\
7. Ash & $-.39^{2}$ & $-.47^{3}$ & $-.57^{3}$ & $-.28^{1}$ & +.18 & $+.40^{2}$ & 1.00 & \\
8. MJ ME/kg DM & $+.59^{3}$ & $+.66^{3}$ & $+.88^{3}$ & -.05 & -.04 & $-.80^{3}$ & $-.60^{3}$ & 1.00 \\
\hline
\end{tabular}

${ }^{1}=\mathrm{P}<0.05^{2}=\mathrm{P}<0.01^{3}=\mathrm{P}<0.001$.

Table 4. Correlation coefficients between physical and chemical characteristics of barley variety Otra, $\mathrm{n}=16$.

\begin{tabular}{lcccccccc}
\hline Characteristics & 1 & 2 & 3 & 4 & 5 & 6 & 7 & 8 \\
\hline 1. Volume w. & 1.00 & & & & & & & \\
2. 1000-kr. w. & $+.79^{3}$ & 1.00 & & & & & & \\
3. Starch + sugars & $+.61^{1}$ & +.35 & 1.00 & & & & & \\
4. Ether extract & $-.64^{2}$ & -.41 & $-.54^{1}$ & 1.00 & & & & \\
5. Crude protein & +.13 & +.40 & $-.56^{1}$ & -.10 & 1.00 & & & \\
6. Crude fibre & $-.89^{3}$ & $-.88^{3}$ & $-.64^{2}$ & $+.65^{2}$ & -.21 & 1.00 & & \\
7. Ash & -.19 & -.12 & -.15 & +.06 & -.05 & +.10 & 1.00 & \\
8. MJ ME/kg DM & $+.79^{3}$ & $+.65^{2}$ & $+.89^{3}$ & $-.65^{2}$ & -.12 & $-.88^{3}$ & -.21 & 1.00 \\
\hline
\end{tabular}

Table 5. Correlation coefficients between physical and chemical characteristics of oats, all samples, $\mathrm{n}=49$.

\begin{tabular}{llllllllll}
\hline Characteristics & 1 & 2 & 3 & 4 & 5 & 6 & 7 & 8 & 9 \\
\hline
\end{tabular}

1. Volume w.

1.00

2. $1000-\mathrm{kr}$. w.

$+.53^{3} \quad 1.00$

3. Hulls

$-.61^{3}-.77^{3} \quad 1.00$

4. Starch + sugars

$+.29^{1}+.50^{3}-.71^{3} \quad 1.00$

5. Ether extracts

$\begin{array}{lllll}-.07 & -.07 & -.10 & +.15 & 1.00\end{array}$

6. Crude protein

$+.44^{2}+.33^{1}-.46^{3}+.38^{2}-.20$

$+.57^{3}+.32^{2}-.67^{3}+.383-.00-1.00$

7. Crude fibre

$\begin{array}{llll}-.57^{3}-.42^{2}+.67^{3}-.71^{3}-.06-.51^{3} & 1.00\end{array}$

8. Ash

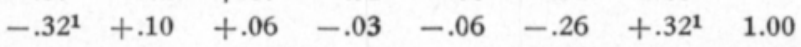

9. $\mathrm{MJ} \mathrm{ME} / \mathrm{kg} \mathrm{DM}$

$+.35^{1}+.56^{3}-.73^{3}+.97^{3}+.25+.53^{3}-.74^{3}-.10$

$1=\mathrm{P}<0.05,{ }^{2}=\mathrm{P}<0.01,{ }^{3}=\mathrm{P}<0.001$

when the starch content is low, the other two, to some degree, compensate for it. The negative correlations also explain the generally known fact that barley with a low energy value has a high content of crude protein. In oats on the contrary, the low starch content is associated with low protein and fat contents. 
Table 6. Correlation coefficients between physical and chemical characteristics of oat variaty Ryhti, $\mathrm{n}=21$.

\begin{tabular}{lccccccccc}
\hline Characteristics & 1 & 2 & 3 & 4 & 5 & 6 & 7 & 8 & 9 \\
\hline 1. Volume w. & 1.00 & & & & & & & & \\
2. 1000-kr. w. & $+.47^{1}$ & 1.00 & & & & & & & \\
3. Hulls & $-.71^{3}$ & $-.69^{3}$ & 1.00 & & & & & & \\
4. Starch + sugars & +.20 & +.07 & $-.52^{1}$ & 1.00 & & & & & \\
5. Ether extract & +.03 & +.36 & -.14 & +.10 & 1.00 & & & & \\
6. Crude protein & $+.54^{2}$ & +.02 & $-.51^{1}$ & +.37 & -.08 & 1.00 & & & \\
7. Crude fibre & $-.54^{2}$ & -.16 & $+.65^{2}$ & $-.84^{3}$ & -.05 & $-.75^{3}$ & 1.00 & & \\
8. Ash & -.41 & -.16 & +.38 & $-.63^{2}$ & -.23 & $-.43^{1}$ & $+.62^{2}$ & 1.00 & \\
9. MJ ME/kg DM & +.33 & +14 & $-.61^{2}$ & $+.94^{3}$ & +.28 & $+.59^{2}$ & $-.92^{2}$ & $-.69^{3}$ & 1.00 \\
\hline
\end{tabular}

Table 7. Relationships between ME values (MJ/kg DM) (y) and three characteristics (x).

\begin{tabular}{|c|c|c|c|}
\hline Characteristics & Regression line & $\mathrm{T}$ value & $\mathrm{R}^{2} \%$ \\
\hline \multicolumn{4}{|l|}{ Volume weight $(87 \% D M)$} \\
\hline 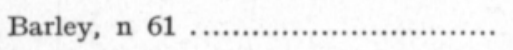 & $\mathrm{y}=11.70+0.032 \mathrm{x}_{1}$ & $+5.61 * * *$ & 35 \\
\hline 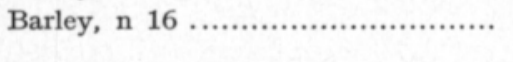 & $y=11.57+0.034 x_{1}$ & $+4.81 * * *$ & 62 \\
\hline 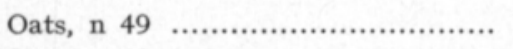 & $y=9.14+0.061 x_{1}$ & $+2.52^{*}$ & 12 \\
\hline Oats, n 21 & $y=9.91+0.046 x_{1}$ & +1.54 & 11 \\
\hline \multicolumn{4}{|l|}{ Crude fibre (\% of DM) } \\
\hline 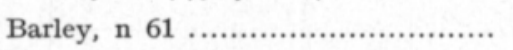 & $y=16.25-0.470 x_{2}$ & $-10.35 * * *$ & 65 \\
\hline 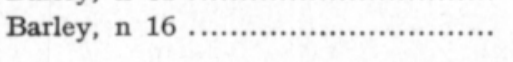 & $y=16.04-0.432 x_{2}$ & $-6.95^{* * *}$ & 78 \\
\hline 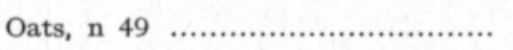 & $y=17.46-0.429 x_{2}$ & $-7.57 * * *$ & 55 \\
\hline 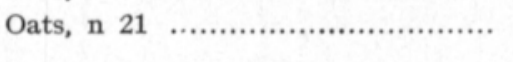 & $y=17.10-0.402 x_{2}$ & $-9.92 * * *$ & 84 \\
\hline \multicolumn{4}{|l|}{ Starch + sugars $(\%$ of $D M)$} \\
\hline 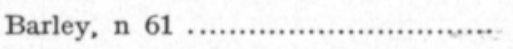 & $\mathrm{y}=5.28+0.145 \mathrm{x}_{\mathrm{s}}$ & $+14.56 * * *$ & 78 \\
\hline Barley, n $16 \ldots \ldots \ldots \ldots \ldots \ldots \ldots \ldots \ldots \ldots \ldots \ldots \ldots \ldots \ldots \ldots \ldots \ldots$ & $y=6.05+c .131 x_{3}$ & $+7.25 * * *$ & 79 \\
\hline 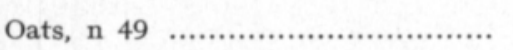 & $y=2.69+0.212 x_{3}$ & $+28.10 * * *$ & 94 \\
\hline 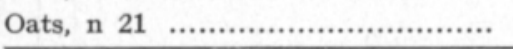 & $\mathrm{y}=2.32+0.219 \mathrm{x}_{3}$ & $+12.08 * * *$ & 88 \\
\hline
\end{tabular}

$*=\mathrm{P}<0.05,{ }^{* *}=\mathrm{P}<0.01,{ }^{* * *}=\mathrm{P}<0.001$

The crude fibre content is a characteristic which has a highly negative effect on the level of volume weight and ME value in both cereals. And, because a great deal of the crude fibre arises from the hulls which contain $40 \%$ crude fibre of DM, these behave as the crude fibre. This adverse influence of crude fibre has been stated by many scientists (e.g. NordFeld et al. 1954, THомке 1960, 1961, SundstøL 1970).

The regression equations (Table 7) further reveal that both starch and crude fibre values gave a good indication of the ME value of barley and oats. The 
starch was a little better than the crude fibre, however, the calculation pattern which was used for the computing of the ME value, might have slightly overestimated the proportion of starch. Regarding analyses, the starch is a little quicker to determine, and the repeatability of results is better than in the case of crude fibre.

The volume weight also gave a good indication for barley, especially within varieties, but for oats it was quite unreliable.

\section{REFERENCES}

Anon. NJF's Fodermiddeltabel. 1969. 40 p. Gjøvik.

ERIKSSON, S., SANNe, S. \& Thomke, S. 1972. Fodermedlen. 251 p. Borås.

GAARdBo Thomsen, M. 1977. Bygsorters fodervaerdi til slagtekyllinger. 460. Beretn. Statens Husdyrbrugs forsog. $60 \mathrm{p}$.

Madsen, A., Bengtsson, A., Krvi, E. \& Mikkelsen, K. 1972. Høsttidspunktets indflydelse på byggens fodervaerdi. Beretn. Forsgsølab. 128 p. København.

Nordfeldt, S., RuUdvere, A., Toiger, A. \& Lagerwall, P. 1954. Digestibility experiments with pigs. Kungl. Lantbr. högsk. Ann. 21:1-29.

PeERs, D. G. \& TAYLoR, A. G. 1977. The influence of the variety of barley and level of nitrogen fertilisation on the digestibility and metabolisable energy value of barley meal in the pig. J. Sci. Fd. Agric. 28: 602-606.

RekUnen, M. 1969. Ohran lajikkeet ja raakavalkuainen. Hankkijan saroilta 10, 1969.

SALO, M.-L. 1965. Determination of carbohydrate fractions in animal foods and faeces. Acta Agric. Fenn. 105: 1-102.

- 1971. Inverkan av havremjölets finhetsgrad på dess smältbarhet hos svin. NJFKongressen 29. juni -2 . juli 1971. Seksjon V. p. 113-114.

- \& SALmi, M. 1968. Determination of starch by the amyloglucosidase method. J. Scient. Agric. Soc. Finl. 40: 38-45.

Schulz, E. \& Oslage, H. J. 1969. Untersuchungen über den Nährwert verschiedener in- und ausländischer Gersten für Schweine. Landw. Forsch. 22: 265-280.

SibBald, I. R. \& PRICE, K. 1976. Relationships between metabolizable energy values for poultry and some physical and chemical data describing Canadian wheats, oats and barley. Can J. Anim. Sci. 56: 255-268.

Sibbaid, I. R. \& PRICE, K. 1797. True and apparent metabolizable energy values for poultry of Canadian wheats and oats measured bioassay and predicted from physical and chemical data. Can. J. Anim. Sci. 57: 365-374.

Sundstøl, F. 1970. Undersøkelser over forverdien av bygg av ulik kvalitet. Beretn. nr. 140. Landbrukshøgsk. Foringsforsøk. Norges Landbrukshøgsk. 61 p.

Tномке, S. 1960. Studies on the digestibility of oats by pigs. Kungl. Lantbr. högsk. Ann. 26: 269-288.

- 1961. Smältbarhetsförsök med havre till får, svin och höns. Prövning av olika kvaliteter. Medd. 73 Statens Husdjursförsök. 23 p.

- 1972. On the influence of different stages of ripeness on the productive value of barley fed to chickens, laying hens, rats and mice. Acta Agric. Scand. 22: 107-120.

Ms received June 26, 1978. 


\section{Eri koostumustekijäin ja energia-arvon välisistä vuorosuhteista ohrassa ja kaurassa, kun hehtolitran paino huomattavasti vaihtelee}

Maija-Liisa Salo

Helsingin yliopiston kotieläintieteen laitos, 00710 Helsinki 71

Tutkimuksessa analysoitiin 61 ohra- ja 49 kauranäytettä. joiden hl-painot vaihtelivat $38-75$ ja $40-65 \mathrm{~kg} / \mathrm{hl}$ väleillä. Koostumuksesta laskettiin muuntokelpoisen energian (ME) ja nettoenergian likimääräiset arvot.

Vaıkka ohran hl-paino ja 1000 jyvän paino vaihteli enemmän kuin kauran, sen ME-arvo vaihteii vähemmän: parhaan ja huonoimman näytteen ME-arvon ero oli ohrassa vain $12 \%$, kaurassa sen sijaan $27 \%$. Viljojen erilaisuus johtui lähinnä siitä, että tärkkelyspitoisuus vaihteli ohrassa vähemmän kuin kaurassa ja lisäksi tärkkelys oli ohrassa negatiivisessa vuorosuh teessa proteiiniin ja rasvaan, mutta kaurassa positiivisessa vuorosuhteessa kumpaankin.

ME-arvoa kuvasivat yksityisistä tekijöistä parhaiten tärkkelys- ja raakakuitupitoisuudet. Tärkkelyksen selitysaste oli ohrassa koko aineiston osalta $78 \%$ ja yleisimmän Otra-lajikkeen näytteissä $79 \%$ sekä kaurassa $94 \%$ ja yleisimmän Ryhti-lajikkeen näytteissä $88 \%$ ja raakakuidun selitysaste vastaavasti $65-78$ ja $55-84 \%$. Myös hl-paino ilmaisi ohran ME-arvon varsin hyvin (koko aineistossa 35 ja Otra-näytteissä $62 \%$ ), mutta kauran arvon hyvin huonosti (koko aineistossa 12 ja Ryhti-näytteissä $11 \%$ ). 